\section{Growing Degree-day Influence on Sprigged Establishment of Two Buffalograss Cultivars}

\author{
Kenton W. Peterson, Robert C. Shearman ${ }^{1}$, Roch E. Gaussoin,
} Garald L. Horst, and Walter H. Schacht

University of Nebraska-Lincoln, Department of Agronomy and Horticulture, 377 Plant Science, Lincoln, NE 68583-0724

Additional index words. turfgrass, establishment, stolonizing, carbohydrate, heat units

\begin{abstract}
Attempts to establish buffalograss [Buchloë dactyloides (Nutt.) Engelm.] turfs from sprigs have been limited and successful stand establishment has been inconsistent. This study was conducted to determine whether accumulated growing degree-days (GDD) and cultivar of harvested sprigs have an effect on buffalograss sprig establishment. Two field studies were conducted on a Tomek silty-clay loam (fine smectitic mesic Pachic Agriudolls) in 2007 and again in 2008. The cultivars Legacy, a hexaploid, and Prestige, a tetraploid, were used in this investigation. Sprigs were harvested and planted on 29 June, 17 July, 31 July, and 15 Aug. in 2007 and 15 May, 4 June, 19 June, 2 July, 21 July, 31 July, and 18 Aug. in 2008. The GDDs were back-calculated from these harvest dates. The harvest date of the sprigs represented 1050, 1380, 1670, and 1980 GDD in 2007 and $120,380,620,840,1200,1400$, and 1720 in 2008. Aboveground buffalograss phytomass and percent buffalograss groundcover data were collected in 2007 and 2008. In 2008, total available sugar and starch content of harvested sprigs were determined for each sprig harvest date. In the 2007 studies, sprigs harvested at 1050 GDDs resulted in the best establishment for both cultivars. In the 2008 studies, 'Legacy' established successfully through 840 GDDs, and 'Prestige' established through 1200 GDDs. Sugar or starch content did not appear to influence sprigging success. These results support the recommendation to establish buffalograss from sprigs harvested before 1050 GDDs for best results.
\end{abstract}

Buffalograss is a warm-season $\left(\mathrm{C}_{4}\right)$ perennial grass native to the Great Plains of North America (Savage, 1934; Shearman et al., 2004). The stolons of buffalograss branch profusely, creating a dense sod (Shearman et al., 2004; Wenger, 1943). Buffalograss grows most vigorously in the late spring through late summer and slows with the onset of cooler nights and shorter days in the fall (Wenger, 1943). It is known for its low nitrogen and water use requirements, drought resistance, and heat tolerance and has attracted increased attention for its potential use in home lawns, golf courses, parks, and grounds areas (Fry, 1995; Harivandi and $\mathrm{Wu}, 1995$; Shearman et al., 2004).

Currently, turf-type buffalograss cultivars are established by seed, sod, or plugs. Many of the problems that were commonly associated with poor establishment of seeded buffalograss have been remedied with the release of newer, turf-type cultivars (Shearman et al., 2005). Buffalograss sod often experiences transplant shock with turfgrass color and quality loss after transplanting (Giese et al., 1997). A similar response has been observed with buffalograss plugs, but prerooted plugs successfully avoid this problem (Johnson

Received for publication 14 Oct. 2009. Accepted for publication 22 Dec. 2009.

${ }^{1}$ To whom reprint requests should be addressed; e-mail rshearman1@unl.edu. ${ }^{\mathrm{y}}$ Mehlich P-3.

${ }^{x}$ Bray $\mathrm{P} 1$.
(1934), rooted and unrooted buffalograss stolons will establish in the same way strawberry (Fragaria sp. L.) runners take root in soil under favorable moisture conditions. In Texas, Ruemmele et al. (1993) reported that sprigged or plugged buffalograss groundcover was equal to that of sodded buffalograss groundcover 12 months after planting. In their study, buffalograss sprig survival was only negatively influenced in their study when temperatures were $-12{ }^{\circ} \mathrm{C}$ or below within 2 weeks after planting.

Planting date may also be a crucial factor for successful establishment of sprigs. Warm-season grasses are best established just before the longest period of favorable growing conditions (Vallentine, 1989). Research in Texas demonstrated that bermudagrass has a narrow sprig establishment window from late spring through midsummer (White, 2004). Gibeault and Cockerham (1988) found that early summer sprigging of zoysiagrass was preferred over spring or fall sprigging. Mueller et al. (1993) recommended spring planting of nondormant bermudagrass sprigs because there is a higher probability of precipitation occurring at that time.

Growing degree-day (GDD) units often are used to predict different plant developmental stages and may be a better means of establishing planting times than arbitrary dates. Temperature can be used with confidence to predict a plant's development stage assuming other growth factors do not change significantly (Tyldesley, 1978; Wang, 1960; Yin et al., 1995). If the growth stage of buffalograss has an influence on establishment from sprigs, then GDDs could be useful in estimating the best date to harvest sprigs for establishment purposes.

Another factor potentially influencing sprig establishment is carbohydrate reserve status of the sprigs before harvest. The predominant storage carbohydrate of warm-season grasses is the glucose polymer starch (Smith, 1968). Warm-season grasses maintain a high carbon dioxide exchange rate and exhibit their most vigorous growth during the summer months (Hull, 1992). Conditions favoring vigorous growth result in lower carbohydrate concentrations than conditions in which photosynthetic rates remain high, but growth is suppressed (Hull, 1992). Stolons of bermudagrass labeled with ${ }^{14} \mathrm{C}$ indicate that new growth on the stolon is a strong photosynthate sink (Forde, 1966). New stolons, acting as strong

Table 1. Soil test results for Field Study Location (FSL) 1 and FSL 2 in 2007 and 2008, respectively. ${ }^{2}$

\begin{tabular}{ccccc}
\hline & $\mathrm{pH}$ & $\begin{array}{c}\text { Organic matter } \\
\left(\mathrm{g} \cdot \mathrm{kg}^{-1}\right)\end{array}$ & $\begin{array}{c}\text { Available } \\
\text { phosphorus }\left(\mathrm{mg} \cdot \mathrm{kg}^{-1}\right)\end{array}$ & $\begin{array}{c}\text { Available } \\
\text { potassium }\left(\mathrm{mg} \cdot \mathrm{kg}^{-1}\right)\end{array}$ \\
\hline FSL 1 & & & & 457 \\
2007 & 5.4 & 40 & $30^{\mathrm{y}}$ & 505 \\
2008 & 5.0 & 38 & $55^{\mathrm{x}}$ & 437 \\
FSL 2 & & & & 375 \\
2007 & 6.1 & 39 & $33^{\mathrm{y}}$ & \\
2008 & 6.8 & 34 & $24^{\mathrm{x}}$ & \\
\hline
\end{tabular}

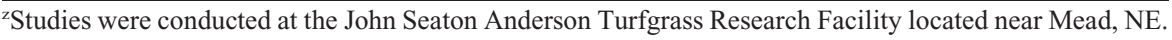


sinks, may not have sufficient carbohydrate reserves available to supplement new root growth when they are separated from the mother plant. This study was conducted to evaluate buffalograss sprig establishment. The objectives were to determine the effect of accumulated GDD, cultivar, and sugar and starch content of harvested buffalograss sprigs on sprig establishment.

\section{Materials and Methods}

This investigation was conducted at the John Seaton Anderson Turfgrass Research Facility (long. 41 $11^{\prime} \mathrm{N}$, lat. 96 $28^{\prime} \mathrm{W}$ ) located near Mead, NE. Two field studies [Field Study Location 1 (FSL1) and Field Study Location 2 (FSL2)], representing diverse conditions based on exposure, slope, and soil acidity, were conducted each year in 2007 and 2008.

The buffalograss cultivars, Legacy and Prestige, were used for sprigging treatments in this investigation. Both cultivars were developed at the University of NebraskaLincoln and have distinct growing and adaptation characteristics suited to Nebraska growing conditions (Johnson et al., 2000; Riordan et al., 2000). 'Legacy' is a hexaploid $(2 \mathrm{n}=6 \mathrm{x}=60)$ and 'Prestige' is a tetraploid $(2 n=4 x=40)$. 'Legacy' is adapted to the northern region of buffalograss adaptation, whereas 'Prestige' grows well in the northern, southern, and central regions of adaptation (Shearman et al., 2004).

Buffalograss sprigs were harvested from a 3-year-old sod grown at Todd Valley Farms, Inc. (long. $41^{\circ} 14^{\prime} \mathrm{N}$, lat. $96^{\circ} 28^{\prime} \mathrm{W}$ ) located near Mead, NE. Sprig harvesting and planting dates for 2007 were 29 June, 17 July, 31 July, and 15 Aug. Based on results observed from the 2007 studies, harvesting and planting dates were expanded for the two field studies conducted in 2008 to include 15 May, 4 June, 19 June, 2 July, 21 July, 31 July, and 18 Aug. These dates were used as end dates for calculating the accumulated GDDs of the harvested sprigs. A dethatching machine (Thatch Master TM-60; Turf Specialties, Inc., Lakeland, FL) was used to harvest the sprigs. Sprigs were harvested at $1030 \mathrm{HR}$ for each harvest date. The harvesting process resulted in sprigs having three to six nodes with leaves remaining attached. Sprigs were stored in plastic containers and kept indoors until being planted within $2 \mathrm{~h}$ of harvest. Sprig temperatures never exceeded $27{ }^{\circ} \mathrm{C}$ from the time of harvest to planting.

Field Study Location 1 (FSL1). Studies were initiated at FSL1 on 29 June in 2007 and on 15 May in 2008. Soil samples were collected and tested for soil acidity, phosphorus, potassium, and organic matter before the first sprigging (Table 1). Soil analysis was conducted by Ward Laboratories, Inc. (Kearney, NE). The FSL1 site was exposed from all directions with no trees or buildings within 180 $\mathrm{m}$. The grade of FSL1 was essentially level, so runoff was limited from the site.

Before the first planting each year, treatment plots were prepared with a rotary tiller hand-raked to loosen the soil surface and weeds were removed by hand before planting each treatment. Buffalograss was sprigged at $11 \mathrm{~m}^{3} \cdot \mathrm{ha}^{-1}$. Sprigs were evenly broadcast by hand and topdressed using a self-propelled topdressing machine (Mete-R-Matic; Turfco Manufacturing, Inc., Minneapolis, MN) to a depth of $0.64 \mathrm{~cm}$ with soil from the site. After topdressing, the plots were rolled using a turf roller (John's Welding \& Tool, Wayne, $\mathrm{NE})$ to ensure good sprig-soil contact. A starter fertilizer $(14 \mathrm{~N}-11 \mathrm{P}-5 \mathrm{~K})$ was applied at a rate of $5 \mathrm{~g} \mathrm{~N} / \mathrm{m}^{2}$ after rolling, and plots were watered deeply immediately after this application with $6 \mathrm{~mm}$ of water.

Two to three irrigation events were applied daily with $5 \mathrm{~mm}$ of water applied each time. Treatment plots were not mowed until turf reached a height of $70 \mathrm{~mm}$. Once mowing was initiated, turfs were mowed once every 2 weeks at a $50-\mathrm{mm}$ mowing height and clippings removed.

Weeds were controlled by hand-weeding and postemergence chemical control in both years with an additional application of a preemergent herbicide in the second year. Glyphosate [N-(phosphonomethyl) glycine] was used to control weeds on treatment plots up to $7 \mathrm{~d}$ before sprigging and was applied to dormant buffalograss turf after the establishment year to control cool-season grasses. Oxadiazon [2-tert-butyl-4-(2,4 dichloro-5isopropoxyphenyl)- $\Delta-1,3,4$-oxadiazolin-5-one] was applied at $3.14 \mathrm{~kg} / \mathrm{a}$.i./ha for pre-emergent weed control. Quinclorac [3,7-dichloro-8-quinolinecarboxylic acid] was applied at $0.84 \mathrm{~kg} /$ a.i./ha to each treatment plot for postemergent weed control.

The experimental design for both studies was a randomized incomplete block with four replications. Treatment design was factorial with buffalograss cultivar (Legacy and Prestige) and planting date as treatment factors. Growing degree-days were back-calculated for each planting date. Data were collected through 21 Oct. and 17 Oct. in the 2007 and 2008 establishment years, respectively. Data also were collected from 15 May through 21 Aug. 2008 on the study site established in 2007.

Visual percent buffalograss groundcover data were recorded on a $0 \%$ (bare soil) to $100 \%$ (full green cover) scale. Data were recorded every 2 weeks after sprigging for
(Lely Roterra, Corvallis, OR). Plots were

the 2007 study and weekly for the 2008 study until the first freeze in the fall. Data for the 2007 and 2008 studies were collected until 21 Oct. and 17 Oct., respectively. Aboveground buffalograss phytomass samples were collected for the 2007 study on 21 Oct. and the 2008 study on 17 Oct. Aboveground buffalograss phytomass was collected by removing a $32-\mathrm{cm}^{2}$ sample from the center of four randomly selected areas based on a grid system. The four samples were combined to represent each treatment plot. Phytomass samples were dried at $75{ }^{\circ} \mathrm{C}$ for $48 \mathrm{~h}$, weighed, and reported as $\mathrm{g} \cdot \mathrm{m}^{-2}$.

Field Study Location 2 (FSL2). Studies were initiated at FSL2 on 29 June in 2007 and on 15 May in 2008. The FSL2 site had a northern exposure with tree lines within $130 \mathrm{~m}$ on the west, $80 \mathrm{~m}$ on the east, and $30 \mathrm{~m}$ to the south. The FSL2 site was sloped so that

Table 2. Summary of mean percent buffalograss groundcover at 2, 4, 6, 8, 10, and 12 weeks after sprigging (WAS) at Field Study Locations 1 and 2 in 2007 .

\begin{tabular}{lrrrrrr}
\hline & \multicolumn{5}{c}{ Weeks after sprigging } \\
\cline { 2 - 6 } GDD $^{\mathrm{z}}$ & 2 & 4 & 6 & 8 & 10 & 12 \\
\cline { 2 - 6 } & \multicolumn{6}{c}{$(\%)$} \\
1050 & 0 & 14 & 33 & 60 & 79 & 87 \\
1380 & 0 & 0 & 1 & 2 & 10 & 10 \\
1670 & 0 & 0 & 2 & 5 & 3 & $\mathrm{NR}$ \\
1980 & 0 & 0 & 1 & 5 & $\mathrm{NR}^{\mathrm{y}}$ & $\mathrm{NR}$ \\
Least significant & $\mathrm{NS}$ & 3 & 5 & 7 & 8 & 8
\end{tabular}

difference $(0.05)$

${ }^{\mathrm{z}}$ Accumulated growing degree-days (GDD) $\left(5^{\circ} \mathrm{C}\right.$ base) of harvested sprigs.

${ }^{y}$ Data not recorded (NR) as a result of termination of the study at the end of the growing season. NS = nonsignificant.

Table 3. Summary of mean aboveground buffalograss phytomass at Field Study Locations 1 and 2 in 2007.

\begin{tabular}{lc}
\hline $\mathrm{GDD}^{\mathrm{z}}$ & $\begin{array}{c}\text { Phytomass } \\
\left(\mathrm{g} \cdot \mathrm{m}^{-2}\right)\end{array}$ \\
\hline 1050 & 472 \\
1380 & 9 \\
1670 & 10 \\
1980 & 1 \\
Least significant difference $(0.05)$ & 61 \\
\hline
\end{tabular}

${ }^{\mathrm{z}}$ Accumulated growing degree-days (GDD) $\left(5^{\circ} \mathrm{C}\right.$ base) of harvested sprigs.

Table 4. Summary of mean percent buffalograss groundcover rated on 15 May, 29 May, 12 June, 26 June, 10 July, 24 July, 7 Aug., and 21 Aug. 2008 from 2007 field studies. ${ }^{z}$

\begin{tabular}{lrrrrrrrr}
\hline & \multicolumn{1}{c}{ Date of eating } \\
\cline { 2 - 9 } GDD $^{\mathrm{y}}$ & \multicolumn{10}{c}{ 15 May } & 29 May & 12 June & 26 June & 10 July & 24 July & 7 Aug. & 21 Aug. \\
\cline { 2 - 9 } & 97 & 99 & 100 & 100 & 100 & 100 & 100 & 100 \\
1050 & 15 & 19 & 30 & 51 & 72 & 86 & 97 & 99 \\
1380 & 17 & 24 & 43 & 62 & 79 & 88 & 98 & 98 \\
1670 & 7 & 9 & 18 & 37 & 60 & 83 & 97 & 99 \\
1980 & 6 & 8 & 12 & 12 & 11 & 7 & NS & NS
\end{tabular}

difference $(0.05)$

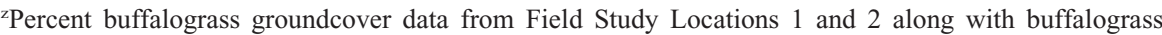
cultivars Legacy and Prestige were combined.

${ }^{y}$ Accumulated growing degree-days (GDD) $\left(5^{\circ} \mathrm{C}\right.$ base $)$ for harvested sprigs.

NS $=$ nonsignificant. 
surface water drained to the east. There was a site difference between FSL1 and FSL2 for soil $\mathrm{pH}$, nutrients, and organic matter content (Table 1). Experimental design, treatment design, soil classification type, sprig establishment methods, treatment plot management, and data collection and analysis were the same as those described for FSL1.

Carbohydrate analysis. Tissue samples consisting of stolons, shoots, and leaves were collected on the same dates as sprig harvest and planting in 2008 and were analyzed for total available sugar (dextrose, glucose, and sucrose) and starch content. Samples were placed on dry ice immediately after sampling, stored at $-20{ }^{\circ} \mathrm{C}$, and dried at $55{ }^{\circ} \mathrm{C}$ for $48 \mathrm{~h}$ before grinding. Sugar and starch determinations were done by Ward Laboratories, Inc. using a YSI 2700 Select Biochemistry Analyzer (YSI Incorporated, Yellow Springs, $\mathrm{OH}$ ).

Growing degree-days. Accumulated GDDs of the harvested sprigs were calculated for each harvest date using the mean-minus-base method (Frank et al., 1998; Gilmore and Rogers, 1958; Katz, 1952; Pruess, 1983). Based on the work of Unruh et al. (1996), the basal growth temperature was $5{ }^{\circ} \mathrm{C}$ using the following formula:

$$
\begin{aligned}
\mathrm{GDD} & =[(\text { maximum daily temperature } \\
& + \text { minimum daily temperature }) / 2]-5^{\circ} \mathrm{C}
\end{aligned}
$$

Growing degree-days were summed for the period after the last freeze $\left(0{ }^{\circ} \mathrm{C}\right.$ temperature) in the spring to the first freeze in the fall. Meteorological data were taken from an automated weather station located near the research plots.

Statistical analysis. Analysis of variance, using the PROC GLM (SAS Institute Inc., Cary, NC) procedure, was used to test for significance $(P<0.05)$. Means were separated using Fisher's protected least significant difference. Regression analysis was conducted using SigmaPlot (Systat Software, Inc., San Jose, CA). Hartley's F-max test was used to determine homogeneity of variances between locations (Hartley, 1950). PROC MEANS was used to estimate treatment means and SES for total sugar and starch content.

\section{Results and Discussion}

2007 FSL1 and 2. Percent buffalograss groundcover and aboveground buffalograss phytomass data from FSL1 and FSL2 were analyzed together based on Hartley's F-max test. Percent buffalograss groundcover data collected in 2008, from the 2007 establishment year, were combined as well.

Percent buffalograss groundcover of sprigs harvested at 1050 GDD was greater than sprigs harvested at 1380, 1670, and 1980 GDD from 4 through 12 weeks after sprigging (WAS) (Table 2). Aboveground buffalograss phytomass at the end of the growing season was also greater for the 1050 GDD sprig harvest treatment than the 1380, 1670, or 1980 GDD sprig harvest treatment (Table
3). Cultivar was not a significant factor in affecting percentage buffalograss groundcover or aboveground buffalograss phytomass in 2007. Soil acidity and site characteristics between the two sites did not affect establishment.

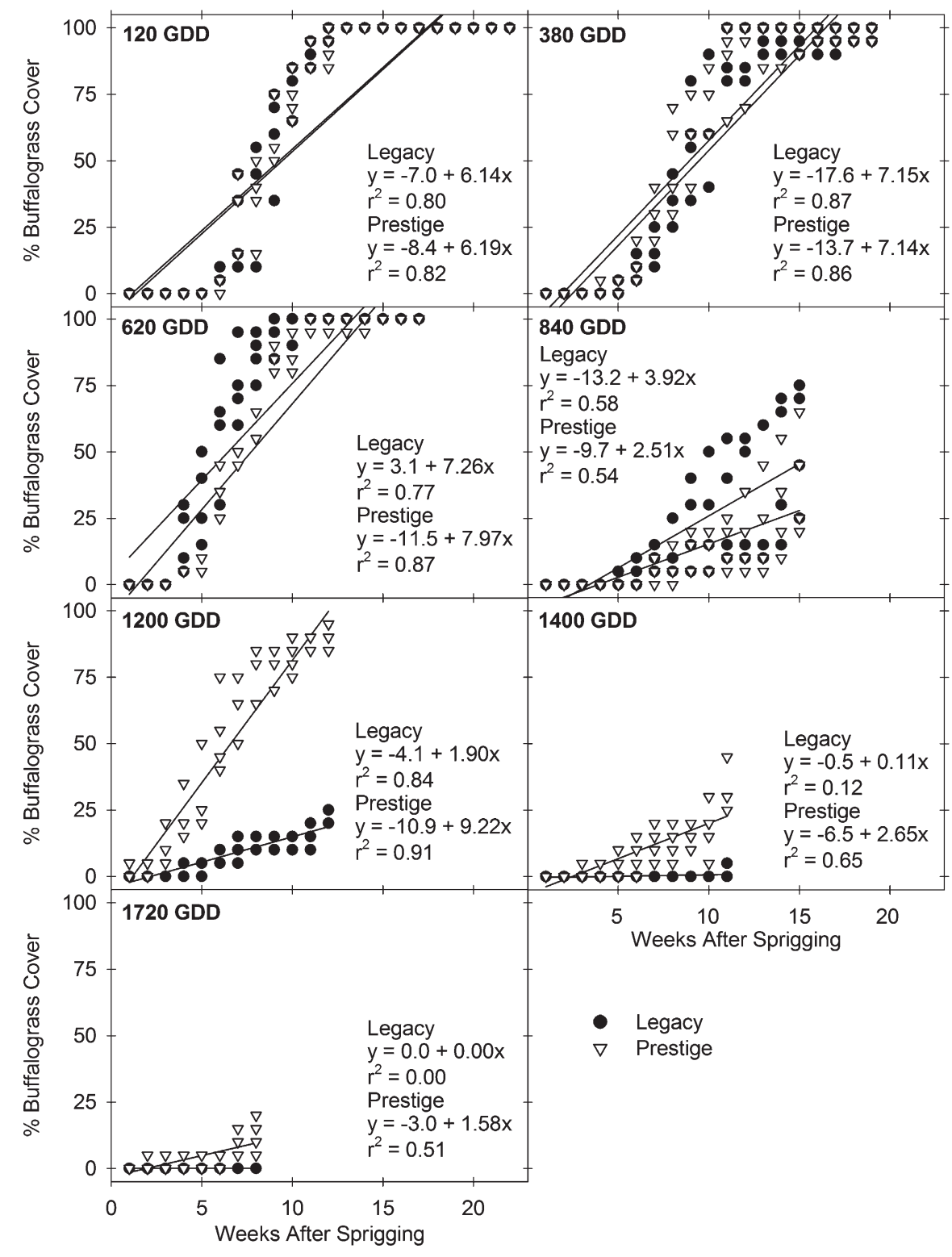

Fig. 1. Summary of percent buffalograss groundcover cultivar $\times$ weeks after sprigging interaction for Field Study Location 1 in 2008. Open triangles and filled circles represent 'Prestige' and 'Legacy', respectively. Equations show the linear regression analysis of all data for each cultivar.

Table 5. Summary of mean percent buffalograss groundcover at 1 through 18 weeks after sprigging (WAS)

\begin{tabular}{|c|c|c|c|c|c|c|c|c|c|c|c|c|c|c|c|c|c|c|}
\hline \multirow[b]{3}{*}{$C D \cap 7$} & \multicolumn{18}{|c|}{ Weeks after sprigging } \\
\hline & 1 & 2 & 3 & 4 & 5 & 6 & 7 & 8 & 9 & 10 & 11 & 12 & 13 & 14 & 15 & 16 & 17 & 18 \\
\hline & \multicolumn{18}{|c|}{$(\%)$} \\
\hline 120 & 0 & 0 & 0 & 0 & 0 & 5 & 27 & 38 & 59 & 76 & 91 & 95 & 100 & 100 & 100 & 100 & 100 & 100 \\
\hline 380 & 0 & 0 & 0 & 1 & 3 & 11 & 22 & 43 & 60 & 68 & 87 & 89 & 96 & 96 & 96 & 97 & 97 & 98 \\
\hline 620 & 0 & 0 & 0 & 11 & 21 & 46 & 62 & 73 & 91 & 93 & 99 & 99 & 99 & 99 & 100 & 100 & 100 & NR \\
\hline 840 & 0 & 0 & 0 & 0 & 1 & 0 & 6 & 9 & 17 & 18 & 23 & 25 & 29 & 38 & 46 & NR & NR & NR \\
\hline 1200 & 1 & 2 & 5 & 13 & 16 & 31 & 35 & 43 & 44 & 48 & 51 & 56 & NR & NR & NR & NR & NR & NR \\
\hline 1400 & 0 & 0 & 1 & 1 & 3 & 4 & 6 & 6 & 7 & 9 & 17 & NR & NR & NR & NR & NR & NR & NR \\
\hline 1720 & 0 & 1 & 1 & 1 & 1 & 0 & 4 & 6 & $\mathrm{NR}^{\mathrm{y}}$ & NR & NR & NR & NR & NR & NR & NR & NR & NR \\
\hline $\begin{array}{l}\text { Least significant } \\
\text { difference }(0.05)\end{array}$ & NS & 1 & 2 & 4 & 6 & 8 & 8 & 10 & 11 & 10 & 9 & 10 & 13 & 13 & 12 & 2 & 2 & \\
\hline
\end{tabular}
for Field Study Location 1 in 2008.

${ }^{\mathrm{z}}$ Accumulated growing degree-days (GDD) $\left(5^{\circ} \mathrm{C}\right.$ base) of harvested sprigs.

${ }^{y}$ Data not recorded (NR) as a result of termination of the study at the end of the growing season.

$\mathrm{NS}=$ nonsignificant. 
Weed encroachment during sprig establishment was a problem, especially for the 1380 , 1670, or 1980 GDD sprig harvest treatments. These treatments lacked buffalograss groundcover, which allowed weeds to grow without competition. Research is needed to determine herbicides that can be effectively used for weed management during sprig establishment.

Cultivar and GDD affected percent buffalograss groundcover in the second year on 2007 sites (Table 4). Groundcover on 15 May, 29 May, and 12 June 2008 was $6 \%, 8 \%$, and $9 \%$, respectively, greater for 'Prestige' than 'Legacy'. However, both cultivars reached 95\% groundcover by 7 Aug. 2008. Groundcover was greater for the 1050 GDD sprig harvest treatment on 15 May, 29 May, 12 June, 26 June, 10 July, and 24 July 2008 than the 1380,1670 , or 1980 GDD sprig harvest treatments (Table 4). All GDD treatments reached $95 \%$ groundcover by 7 Aug. 2008 . The establishment response in the second year was unexpected. Sprigs were exposed to desiccation during the winter months without sufficient protection. During the winter of 2007 -2008 , FSL1 and FSL2 were snow-covered for much of December through February. This snow cover may have provided protection from desiccation and the insulation may have helped prevent direct low-temperature injury for sprigs that did not appear to establish during the 2007 growing season. Several researchers have reported that desiccation prevention is important to sprig survival (Beard, 1973; Beaty, 1966; Chamblee and Gooden, 1981; Watschke and Schmidt, 1992; Webb, 1959). Although the delayed sprig establishment observed in this study is interesting, it would be less than desirable and would not be acceptable for most turfgrass establishment situations. In addition, weed competition could be a problem and would likely limit buffalograss establishment unless efforts were made to keep them under control.

2008 field studies. Percent buffalograss groundcover data from FSL1 and FSL2 were not analyzed together, in 2008, based on Hartley's F-max test. Aboveground buffalograss phytomass data were combined for FSL1 and FSL2.

In 2008, FSL1 had a significant GDD $\times$ cultivar interaction from 2 through 12 WAS for percent buffalograss groundcover (Fig. 1). Establishment rates for 'Legacy' and 'Prestige' were similar at 120, 380, and 620 GDD. 'Legacy' had a greater establishment rate at 840 GDD and 'Prestige' at 1200, 1400, and 1720 GDD. The 1200 GDD sprig harvest treatment exhibited a large separation between cultivars in percent groundcover with 'Prestige' having $69 \%$ greater percent groundcover. Sprigs harvested at 120,380, and 620 GDD resulted in $100 \%, 97 \%$, and $100 \%$ buffalograss groundcover at 17 WAS, respectively (Table 5). Sprigs of 'Legacy' and 'Prestige' harvested at 120, 380, and 620 GDD and 'Prestige' harvested at 1200 GDD resulted in $70 \%$ or greater buffalograss groundcover by the conclusion of data collection in Fall 2008 (Fig. 1).
In 2008, FSL2 had a significant GDD $\times$ cultivar interaction from 3 through 12 WAS for percent buffalograss groundcover (Fig.
2). Establishment rates for 'Legacy' and 'Prestige' were similar at 120, 380, 620, 840 , and 1720 GDD. 'Prestige' had a greater

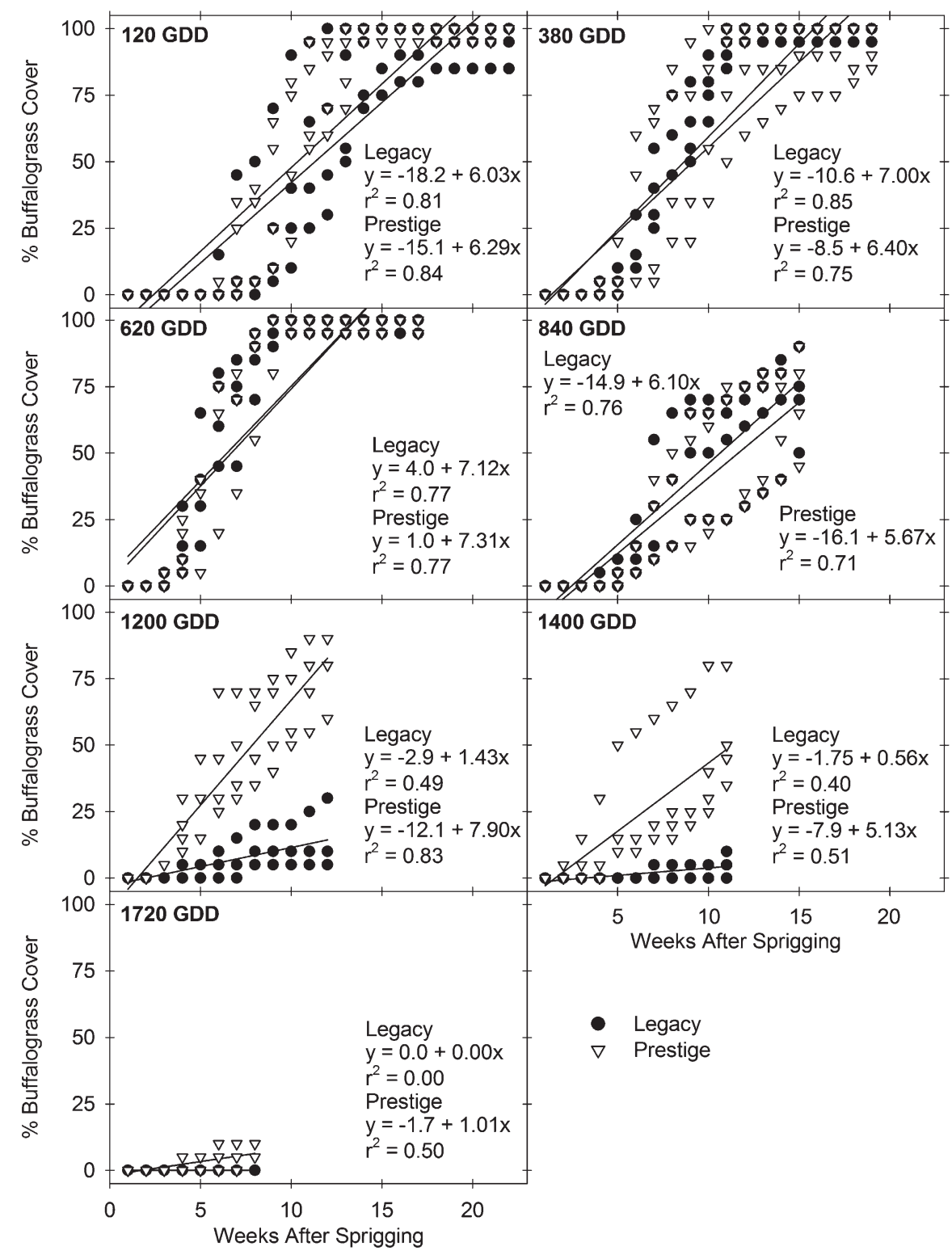

Fig. 2. Summary of percent buffalograss groundcover cultivar $\times$ weeks after sprigging interaction for Field Study Location 2 in 2008. Open triangles and filled circles represent 'Prestige' and 'Legacy', respectively. Equations show the linear regression analysis of all data for each cultivar.

Table 6. Summary of mean percent buffalograss groundcover at 1 through 18 weeks after sprigging (WAS) for Field Study Location 2 in 2008.

\begin{tabular}{|c|c|c|c|c|c|c|c|c|c|c|c|c|c|c|c|c|c|c|}
\hline & \multicolumn{18}{|c|}{ Weeks after sprigging } \\
\hline & 1 & 2 & 3 & 4 & 5 & 6 & 7 & 8 & 9 & 10 & 11 & 12 & 13 & 14 & 15 & 16 & 17 & 18 \\
\hline $\mathrm{GDD}^{\mathrm{z}}$ & \multicolumn{18}{|c|}{ (\%) } \\
\hline 120 & 0 & 0 & 0 & 0 & 0 & 3 & 14 & 18 & 33 & 48 & 65 & 70 & 80 & 91 & 94 & 96 & 96 & 97 \\
\hline 380 & 0 & 0 & 0 & 2 & 6 & 23 & 38 & 55 & 59 & 73 & 86 & 91 & 93 & 93 & 94 & 94 & 94 & 94 \\
\hline 620 & 0 & 0 & 1 & 15 & 33 & 61 & 68 & 84 & 96 & 98 & 99 & 99 & 99 & 99 & 99 & 99 & 99 & $\mathrm{~N}$ \\
\hline 840 & 0 & 0 & 0 & 1 & 4 & 12 & 25 & 35 & 46 & 48 & 51 & 56 & 61 & 66 & 71 & NR & NR & $\mathrm{N}$ \\
\hline 1200 & 0 & 0 & 3 & 11 & 15 & 24 & 26 & 33 & 35 & 39 & 43 & 47 & NR & NR & NR & NR & NR & $\mathrm{N}$ \\
\hline 1400 & 0 & 1 & 3 & 5 & 11 & 12 & 15 & 17 & 18 & 24 & 29 & NR & NR & NR & NR & NR & NR & $\mathrm{N}$ \\
\hline 1720 & 0 & 0 & 0 & 1 & 2 & 3 & 3 & 3 & $\mathrm{NR}^{\mathrm{y}}$ & NR & NR & NR & NR & NR & NR & NR & NR & NR \\
\hline $\begin{array}{l}\text { Least significant } \\
\text { difference }(0.05)\end{array}$ & NS & NS & 2 & 6 & 9 & 13 & 17 & 16 & 20 & 20 & 17 & 17 & 17 & 12 & 11 & NS & NS & NS \\
\hline
\end{tabular}

${ }^{\mathrm{z}}$ Accumulated growing degree-days (GDD) $\left(5^{\circ} \mathrm{C}\right.$ base $)$ of harvested sprigs.

${ }^{y}$ Data not recorded (NR) as a result of termination of the study at the end of the growing season. $\mathrm{NS}=$ nonsignificant 
establishment rate at 1200 and 1400 GDD. Sprigs harvested at 120, 380, and 620 GDD resulted in $96 \%, 94 \%$, and $99 \%$ buffalograss groundcover at 17 WAS, respectively (Table 6). Sprigs of 'Legacy' and 'Prestige' harvested at 120, 380, 620, and 840 GDD and 'Prestige' harvested at 1200 GDD resulted in $70 \%$ or greater buffalograss groundcover by the conclusion of data collection in Fall 2008 (Fig. 2).

Aboveground buffalograss phytomass data resulted in significant GDD $\times$ cultivar interaction. A negative relationship was observed between aboveground buffalograss phytomass and accumulated GDD of harvested sprigs (Fig. 3). As GDD increased, aboveground buffalograss phytomass decreased. 'Legacy' exhibited a greater negative slope than did 'Prestige' with increasing GDDs (Fig. 3). Sprigs harvested at 120, 380, and 620 GDD produced the greatest percent buffalograss groundcover (Tables 5 and 6) and also produced the greatest aboveground buffalograss phytomass (Fig. 3).

Early-season sprig harvesting did not affect buffalograss establishment. The 120 GDD sprig harvest coincided with the break of dormancy for buffalograss. Harvested sprigs of 'Legacy' appeared to have come out of dormancy and green up had begun at the time of harvest. 'Prestige' appeared to be coming out of dormancy because sprigs showed only a little green color.

Sugar and starch content. Carbohydrate content of the harvested sprigs did not influence buffalograss establishment. No trend was observed between total available sugar and starch content and successful sprig establishment. A decline in starch content was observed from the 840 GDD to the 1200 GDD sprig harvest (Fig. 4). The decline in starch content occurred during the period of optimum growing temperatures for warmseason grasses (Beard, 1973). Climatic conditions at 840 GDDs may be the beginning point for conditions that support rapid growth, which may have resulted in the observed lower carbohydrate content. Hull (1992) reported that carbohydrates did not accumulate in storage organs when grasses are growing rapidly. Increasing starch reserves from 'Prestige' after the 1200 GDD sprig harvest likely represent buffalograss storing starch after the rapid summer growth. The starch content difference observed between 'Legacy' and 'Prestige' after 1200 GDD may be attributed to differences in carbohydrate use.

These results provide insight into the developmental changes of buffalograss throughout the growing season and how that might influence successful sprig establishment. The age or growth stage of the harvested sprigs appears to be the main factor influencing their establishment. The most rapidly growing sprigs were harvested early in the growing season, before the peak of warm-season grass growth. The nodes on buffalograss stolons likely begin to mature and new growth lessens as GDDs accumulate. More research is needed to understand the physiological and morpho- logical development of buffalograss stolons. Based on the findings of this investigation, calculating the accumulated GDDs of harvested sprigs can be used to predict the establishment success potential of buffalograss from sprigs. Harvesting sprigs before
1050 GDD is recommended for successful sprig establishment. However, the GDD threshold for successful sprig establishment may be different among cultivars and specific GDD limits should be determined for each cultivar before sprigging.

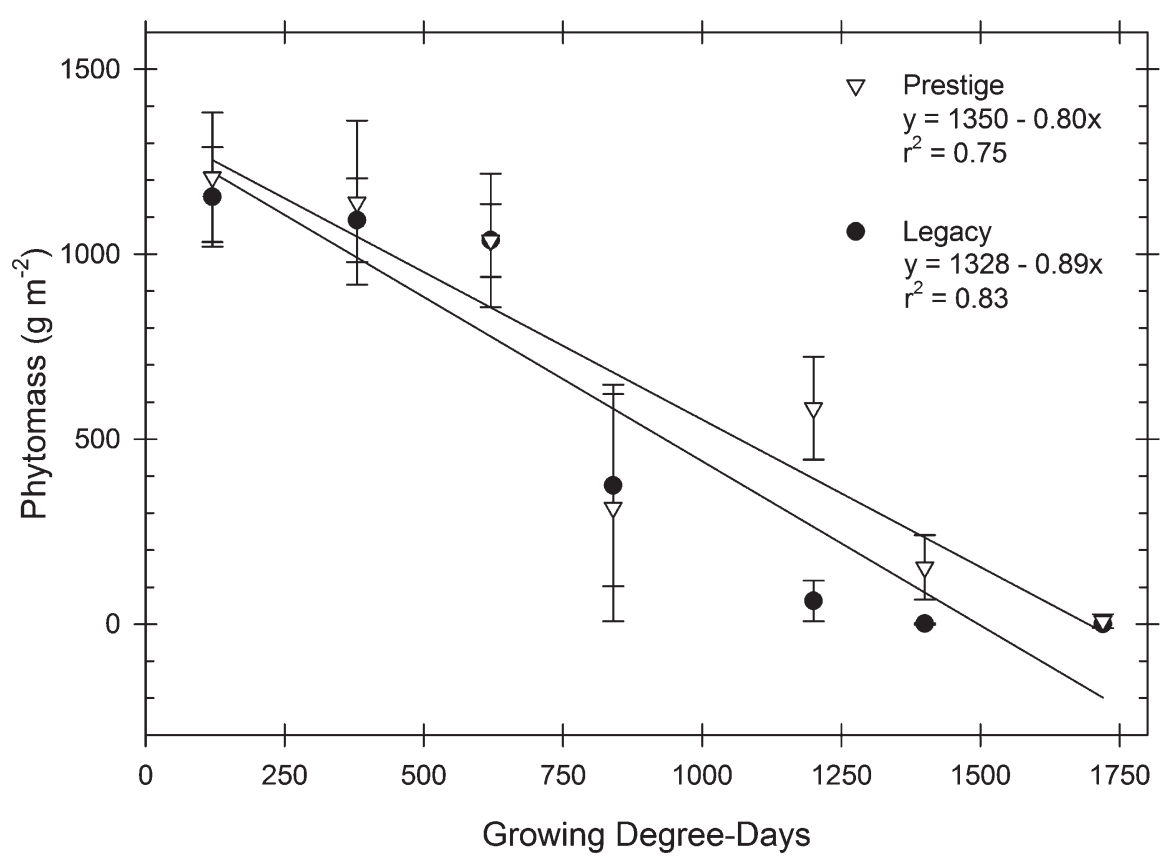

Fig. 3. Summary of mean aboveground buffalograss phytomass for Field Study Locations 1 and 2 combined data in 2008. Open triangles and filled circles represent 'Prestige' and 'Legacy', respectively. Error bars represent the SE of 5\%. Equations show the linear regression analysis of all data for each cultivar.

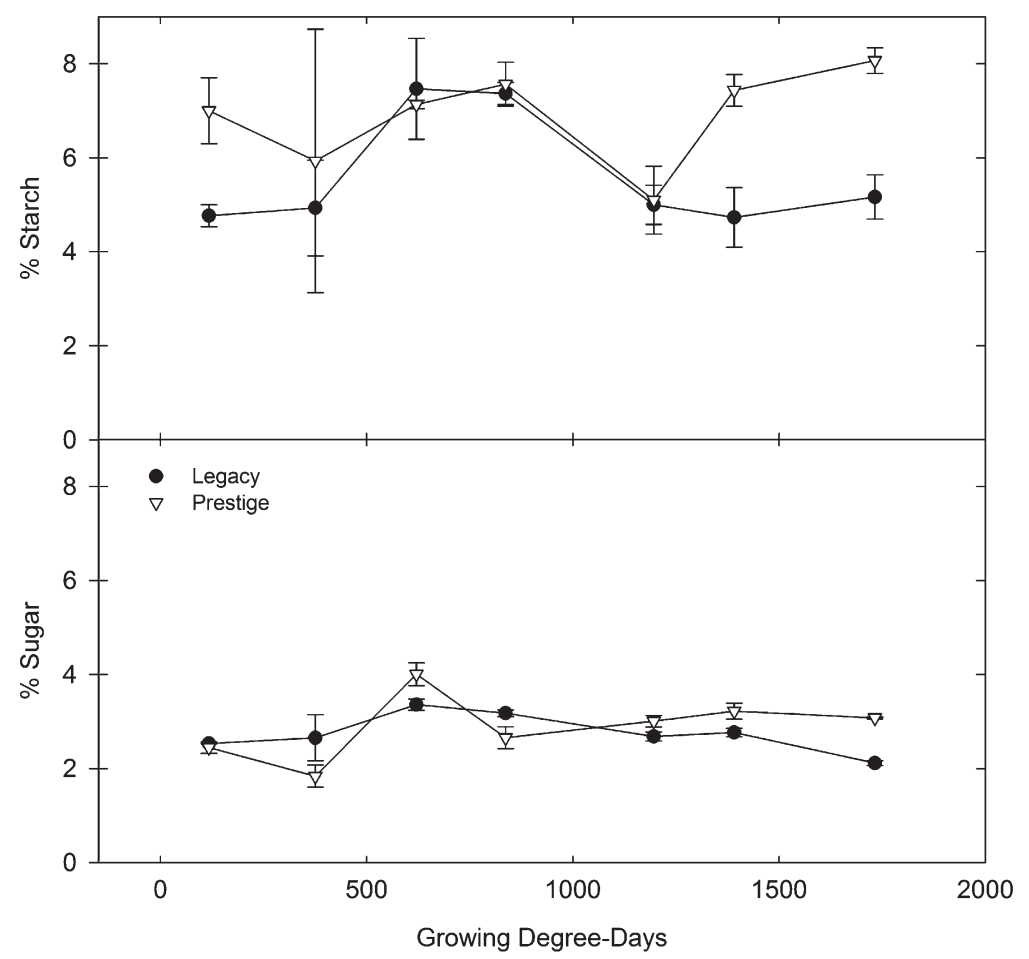

Fig. 4. Sugar and starch content of harvested sprigs expressed as percent of dry weight. Open triangles and filled circles represent 'Prestige' and 'Legacy', respectively. Error bars represent the SE of 5\%. 


\section{Literature Cited}

Beard, J.B. 1973. Turfgrass: Science and culture. Prentice-Hall, Englewood Cliffs, NJ.

Beaty, E.R. 1966. Sprouting of Coastal bermudagrass stolons. Agron. J. 58:555-556.

Chamblee, D.S. and D.T. Gooden, III. 1981. Desiccation, temperature, and degree of dormancy of sprigs influence on establishment of Coastal bermudagrass. Agron. J. 73:872-876.

Forde, B.J. 1966. Translocation in grasses. 1. Bermudagrass. N.Z. J. Bot. 4:479-495.

Frank, K.W., R.E. Gaussoin, T.P. Riordan, and E.D. Miltner. 1998. Date of planting effects on seeded turf-type buffalograss. Crop Sci. 38:1210-1213.

Fry, J.D. 1995. Establishing buffalograss. Golf Course Manage. 63:58-60.

Gibeault, V.A. and S.T. Cockerham. 1988. Zoysiagrass establishment. Coop. Ext. Univ. of California. 38(1\&2).

Giese, M.S., R.E. Gaussoin, R.C. Shearman, and T.P. Riordan. 1997. Sod production characteristics of turf-type Buchloe dactyloides. Intl. Turfgrass Soc. Res. J. 8:455-465.

Gilmore E.C., Jr. and J.S. Rogers. 1958. Heat units as a method of measuring maturity in corn. Agron. J. 50:611-615.

Harivandi, A. and L. Wu. 1995. Buffalograss-A promising drought-resistant turf for California. Coop. Ext. Univ. of California. 45(1\&2).

Hartley, H.O. 1950. The maximum F-ratio as a short-cut test for heterogeneity of variance. Biometrika 37:308-312.

Hull, R.J. 1992. Energy relations and carbohydrate partitioning in turfgrasses, p. 175-205. In: Waddington, D.V., R.N. Carrow, and R.C. Shearman (eds.). Turfgrass. Agron. Monogr. 32. ASA, CSSA, and SSSA, Madison, WI.

Johnson, P.G., T.P. Riordan, R.E. Gaussoin, D.J. Schwarze, and K.A. Kerner. 1997. Vegetative establishment of Buchloe dactyloides (Nutt.)
Engelm. with plugs. Intl. Turfgrass Soc. Res. J. 8:467-476.

Johnson, P.G., T.P. Riordan, J. Johnson-Cicalese, F.P. Baxendale, R.E. Gaussoin, R.C. Shearman, and R.V. Klucas. 2000. Registration of ' 61 ' buffalograss. Crop Sci. 40:569-570.

Katz, Y.H. 1952. The relationship between heat unit accumulation and the planting and harvesting of canning peas. Agron. J. 44:74-78.

Mueller, J.P., T.J. Green, Jr., D.S. Chamblee, J.C. Burns, J.E. Bailey, and R.L. Brandenburg. 1993. Bermudagrass management in North Carolina. AG-493. N. Car. Coop. Ext. North Carolina State Univ., Raleigh, NC.

Musser, H.B. and A.T. Perkins. 1969. Guide to planting, p. 474-490. In: Hanson, A.A. and F.V. Juska (eds.). Turfgrass science. Agron Monogr. 14. ASA, Madison, WI.

Pruess, K.P. 1983. Day-degree methods for pest management. Environ. Entomol. 12:613619.

Riordan, T.P., P.G. Johnson, J. Johnson-Cicalese, R.E. Gaussoin, F.P. Baxendale, R.C. Shearman, and R.V. Klucas. 2000. Registration of ' 118 ' buffalograss. Crop Sci. 40:570-571.

Ruemmele, B.A., M.C. Engelke, S.J. Morton, and R.H. White. 1993. Evaluating methods of establishment for warm-season turfgrasses. Intl. Turfgrass Soc. Res. J. 7:910-916.

Savage, D.A. 1934. Methods of reestablishing buffalo grass on cultivated land in the Great Plains. Circulation 328. USDAWashington, DC.

Shearman, R.C., H. Budak, S. Severmutlu, and R.E. Gaussoin. 2005. Bur seeding rate effects on turf-type buffalograss establishment. HortTechnology 15:246-249.

Shearman, R.C., T.P. Riordan, and P.G. Johnson. 2004. Buffalograss, p. 1003-1026. In: Moser, L.E., B.L. Burson, and L.E. Sollenberger (eds.).
Warm-season (C-4) grasses. Agronomy Monograph No. 45. American Society of Agronomy, Madison, WI.

Smith, D. 1968. Classification of several native North American grasses as starch or fructosan accumulators in relation to taxonomy. Grass Forage Sci. 23:306-309.

Tyldesley, J.B. 1978. A method of evaluating the effect of temperature on an organism when the response in non-linear. Agr. Meteorol. 19:137153.

Unruh, J.B., R.E. Gaussoin, and S.C. Wiest. 1996. Basal growth temperatures and growth rate constants of warm-season turfgrass species. Crop Sci. 36:997-999.

Vallentine, J.F. 1989. Range development and improvements. 3rd Ed. Academic Press, San Diego, CA.

Wang, J.Y. 1960. A critique of the heat unit approach to plant response studies. Ecology 41:785-790

Watschke, T.L. and R.E. Schmidt. 1992. Ecological aspects of turf communities, p. 129174. In: Waddington, D.V., R.N. Carrow, and R.C. Shearman (eds.). Turfgrass. Agron. Monogr. 32. ASA, CSSA, and SSSA, Madison, WI.

Webb, B.C. 1959. Comparison of water loss and survival of Coastal bermudagrass stolons harvested at two stages of growth. Agron. J. 51: 367-368.

Wenger, L.E. 1943. Buffalograss. Bull. 321. Kans. Agric. Exp. Stn., Manhattan, KS

White, C.B. 2004. Turf establishment: Peephole or panorama? USGA Green Section Record. 42:10-12.

Yin, X., M.J. Kropff, G. McLaren, and R.M. Visperas. 1995. A nonlinear model for crop development as a function of temperature. Agr. For. Meteorol. 77:1-16. 